Department of Anatomy (Prof. W. Bargmann) and Department of Zoology (Prof. E. Kullmann), Kiel University, Germany

\title{
Enzyme Histochemical and Ultrastructural Observations on the Liver of Teleost Fishes*
}

\author{
Ulrich N. WeLsCH and Volker N. STORCH
}

\author{
Received April 9, 1973
}

\begin{abstract}
Summary. The liver of eight freshwater and marine teleost species originating from temperate and tropical waters, have been studied with histochemical methods and with the electron microscope. Marked species differences have been found in respect to enzyme activities, lipid and glycogen contents as well as to the ultrastructural characters of the hepatocytes. Alkaline phosphatase was found in the majority of species predominantly along the sinusoids and possibly also along the bile canaliculi. Cholin-esterase was found in the same localization as alkaline phosphatase, but was usually detected only in low concentrations. Lysosomal enzymes (E 600 resistent esterase, acid phosphatase, $\beta$-glucuronidase, $\beta$-glucosaminidase, $\beta$-galactosidase) were observed generally in moderate or weak, rarely also in strong concentrations. NADH- and NADPH-diaphorases are of strong or moderate intensities and are usually evenly distributed in the tissue. Limanda limanda, Tetraodon fuviatilis were the species with the highest lipid contents in the hepatocytes; Chromis, Amphiprion and Corydoras are particularly rich in glycogen. The hepatocytes of all species contain membrane-bound inclusion bodies which, according to their ultrastructure, are interpreted to represent peroxisomes. In most species intercellular bile canaliculi occur. The space of Disse is characterized by the absence of a basement lamina and the presence of a few filament-rich cells extending long cellular processes which are interconnected by desmosomes. Special lipid-containing cells were not been observed in the space of Disse.
\end{abstract}

The older light microscopical literature dealing with the liver of fishes is predominantly concerned with the microanatomical arrangement of the hepatocytes and their relationship to blood vessels and biliary ducts (EBERTH, 1867; Hering, 1867; Shore and Jones, 1889; Braus, 1896; Krause, 1922; Siwe, 1937; Elias and Bengelsdorf, 1952; Ito, Watanabe and TAKahashi, 1962). A second major field of interest centers around the ability of the teleost hepatocytes to store vast quantities of glycogen or lipid (in addition to the above mentioned authors: EBITANI, 1961ab, 1962; YAMAмото, 1964). Iто et al. (1962) found species differences in regard to the amount of stored lipid or glycogen. In the carp (Cyprinus carpio), these authors observed seasonal changes in the quantities of the stored energy depots. In Oryzias latipes EBITANI (1961ab, 1962) found that the quantities of stored lipid and glycogen are dependent on the water temperature. Yамамото (1964) found that in the hepatocytes of the goldfish (Carassius auratus) the amount of glycogen decreases under the condition of starvation and that at the same time increased numbers of lipoprotein-triglyceride complexes are incorporated into the cytoplasm. ITo and SHIBASAKI (1968) summarize the literature on special fat-storing cells in the liver of various vertebrates, which also occur in fishes and which are located in the space of Disse.

Ultrastructural observations on the fish hepatocytes mainly concern the goldfish

* Supported by the Deutsche Forschungsgemeinschaft (We 380/4, Sto 75/2) 
(DAvid, 1961; Yамамото, 1964, 1965). In normal goldfish YАмамото describes abundant mitochondria and elements of rough endoplasmic reticulum and a Golgi apparatus which is located near the bile canaliculi. These canaliculi have been found to occur intracellularly (ҮАмамото, 1965) and to show abrupt transitions to unicellular bile ducts terminating at the surface of the liver cells.

In the present paper the above mentioned findings shall be extended by enzymehistochemical and ultrastructural findings on eight marine and freshwater teleost species originating from the Baltic Sea and tropical waters.

\section{Material and Method}

Gadus morrhua and Limanda limanda were collected from the Baltic Sea. Tetraodon fluviatilis, Amphiprion percula and Dascyllus trimaculatus were collected in Thailand. For control the SE-Asian species and addition Hippocampus hippocampus, Chromis chromis and Corydoras paleatus were obtained from local dealers. These animals were kept under identical conditions and killed at noon. The Baltic species were caught in January, the tropical species in July.

\section{Enzyme histochemistry}

Unfixed frozen cryostat sections of the liver were incubated for NADH- and NADPH-diaphorases (PEARSE, 1968). Cold formaline-fixed sections of the same material were incubated for: 4-chloro-5-bromoindoxyl acetate esterase (HoL T 1958), E 600 resistent indoxyl acetate esterase (HoL T, 1958), $\beta$-glucosaminidase (PUGH and W ALKER, 1958), $\beta$-galactosidase (RUTENBERG et al., 1958), $\beta$-glucuronidase (HAYASHI's method after PEARSE, 1972) acid phosphatase (BARKA and ANDERson, 1962), acetylcholinesterase (Gomori, 1952), alkaline phosphatase (Burstone, 1958, and Gomori-method after PEARSE, 1972).

For the demonstration of lipids the Sudan-black-method (RomeIs, 1968) was used.

\section{Electron microscopy}

Small pieces of liver were fixed in cold 3.5\% glutaraldehyde ( $\mathrm{pH} \mathrm{7.5)} \mathrm{for} 2 \mathrm{hrs}$. After repeated rinsing in cold phosphate buffer $(\mathrm{pH} 7.6)$ the material was postfixed in $2 \% \mathrm{OsO}_{4}$, dehydrated in ethanol, transferred for $15 \mathrm{~min}$ to propylenoxide and embedded in araldite. Thin sections were stained for 5 min each with lead citrate and uranyl-acetate (saturated solution in 70\% methanol). Electron microscopes: Zeiss EM 9A and Siemens 101.

\section{Observations}

Unless stated otherwise, the following description refers to the hepatocytes.

\section{Enzyme histochemistry (Table 1)}

NADH- and NADPH-diaphorases (Fig. 2a, b). Both enzymes show an even distribution in the liver tissue, NADPH-diaphorase always giving a weaker reaction than NADH-diaphorase. The latter is generally of strong to moderate intensity. A particularly weak reaction for both enzymes was found in Hippocampus (Table 1).

4-Chloro-5-bromoindoxyl acetate esterase (Fig. 2e). This enzyme is generally of moderate intensity and either of uniform intracellular distribution (Tetraodon-Fig. 2e, Dascyllus) or concentrated near the bile canaliculi (Amphiprion, Corydoras, Gadus); 
Table 1. Summarizing the histochemical findings

\begin{tabular}{|c|c|c|c|c|c|c|c|}
\hline & Gadus & Tetraodon & $\begin{array}{l}\text { Amphi- } \\
\text { prion }\end{array}$ & $\begin{array}{l}\text { Hippo- } \\
\text { campus }\end{array}$ & Corydoras & Dascyllus & Limanda \\
\hline NADH-Diaph. & W & $H$ & H & + & H & W & W \\
\hline NADPH-Diaph. & H & H & H & + & H & H & H \\
\hline Indoxyl-Est. & + & H & H & H & H & H & H \\
\hline E600 res. Est. & $(+)$ & + & $(+)$ & + & + & + & $(+)$ \\
\hline $\mathrm{ChE}$ & - & + & + & $(+)$ & H & H & + \\
\hline Acid phosphatase & H & H & H & H & + & $H$ & $H$ \\
\hline$\beta$-Glucuronidase & $H$ & H & W & H & H & + & $H$ \\
\hline$\beta$-Glucosaminidase & $+/ H$ & $+/ H$ & W & $+/+t$ & H & H & $+/ H$ \\
\hline$\beta$-Galactosidase & + & + & + & - & + & + & $(+)$ \\
\hline Alk. phosphatase & + & + & $H$ & W & + & HI & + \\
\hline Sudan black & H & 冊 & + & $(+)$ & $(+)$ & + & 册 \\
\hline
\end{tabular}

Wl: very strong, $\mathrm{H}$ : strong, $H$ : moderate, + : weak, $(+)$ : very weak, - : absent

in this case the reaction is of strikingly granular appearance. In Dascyllus the reaction product is slightly concentrated around central veins.

E 600 resistent indoxyl acetate esterase (Fig. 2f). This enzyme is usually of granular appearance and of weak intensity.

Cholin-esterase. This enzyme can be either altogether absent (Gadus) or appear in different intensities and locations. In moderate (Corydoras, Dascyllus) to weak (Tetraodon, Amphiprion) intensities it occurs along the lining of the blood capillaries. It could not be decided with certainty whether the reaction also occurred at the surface of the bile canaliculi. An apparently weak granular intracellular reaction may be due to brown pigments.

Acid phosphatase (Fig. 1c, d). This enzyme usually appears in moderate intensity and is of granular appearance and usually concentrated near the bile canaliculi. Its distribution in the liver tissue is even.

$\beta$-Glucuronidase (Fig. 1e, $f$ ). The reaction is generally granular and evenly distributed in the liver tissue; only in Dascyllus is it concentrated around central veins. The reaction product generally is concentrated near the bile canaliculi (Fig. 1e).

$\beta$-Glucosaminidase (Fig. $1 \mathrm{~g}, \mathrm{~h}$ ). The reaction is usually granular and of weak to moderate intensity; only in Amphiprion is it strikingly strong.

$\beta$-Galactosidase. This enzyme is only of weak intensity. In Gadus, Tetraodon and Dascyllus the reaction product is clearly granular, otherwise its distribution in the cell is rather even.

Alkaline phosphatase (Fig. 1a, b). Both methods tested gave similar results. The Gomori method, however, usually was slightly less intensive. An intracellular weak, fine-granular reaction was observed in Tetraodon, Gadus and Limanda, in the other species the reaction product occurs along the linings of the blood sinusoids and 


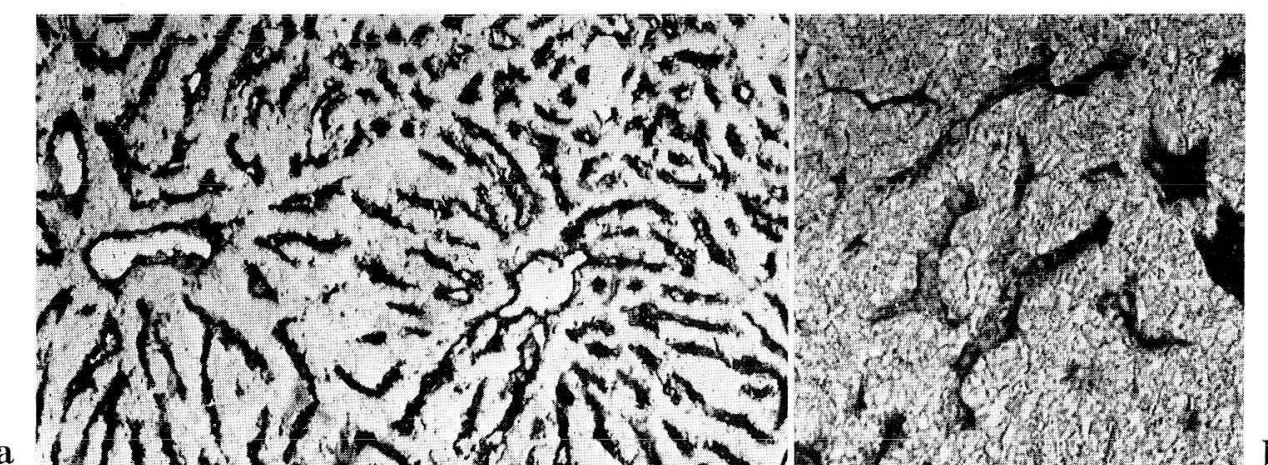

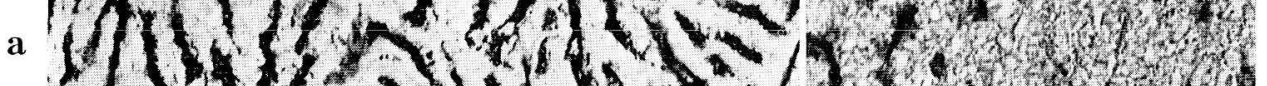

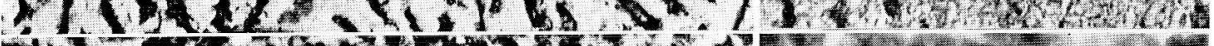

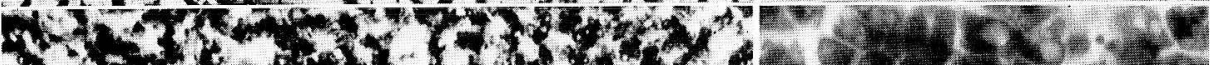
F.

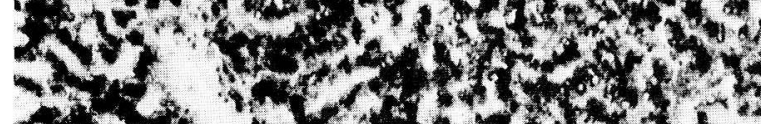

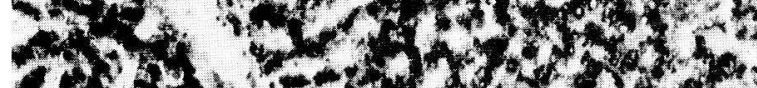

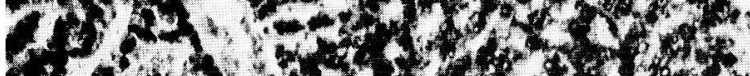

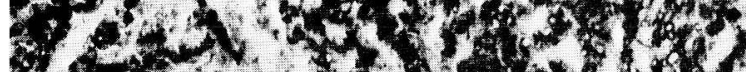

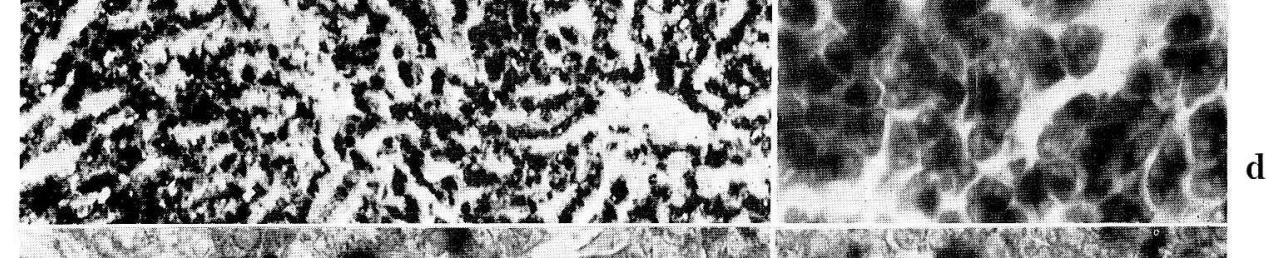

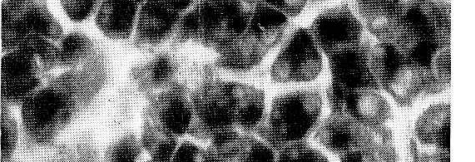

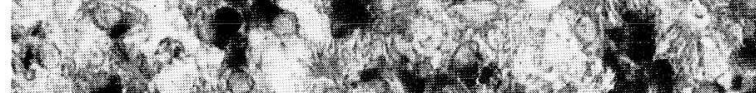

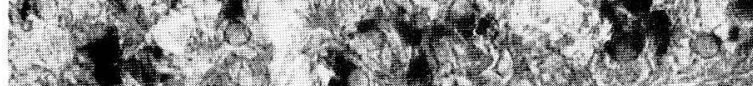

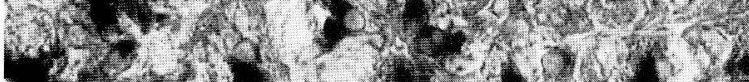

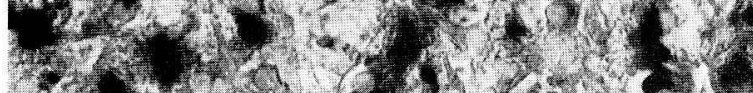

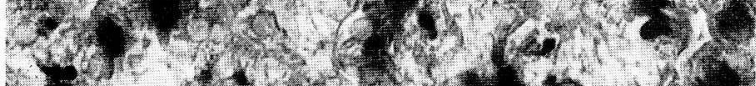

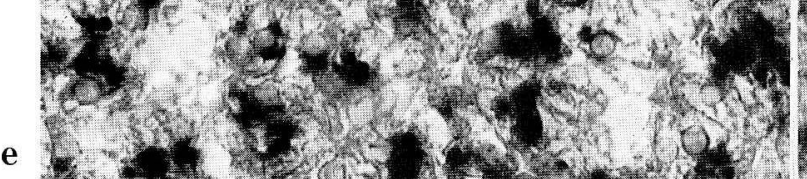
2.

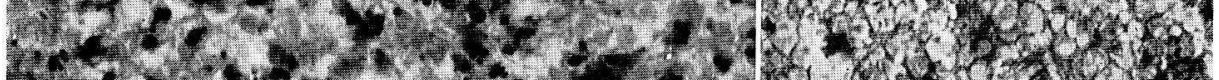

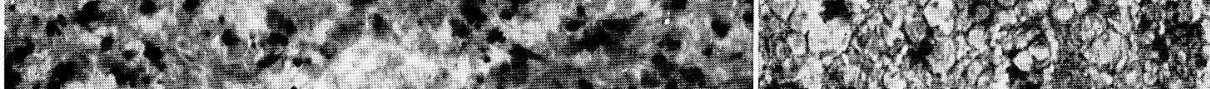

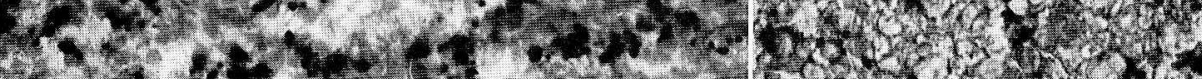

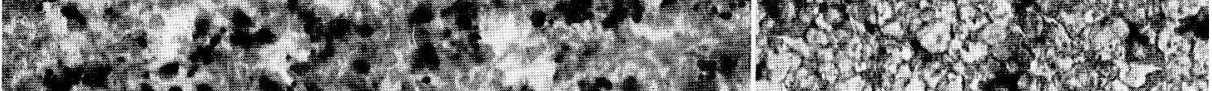

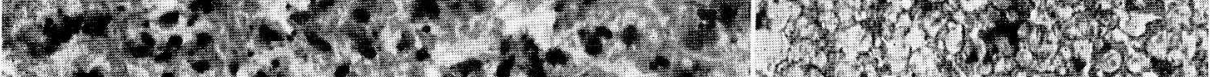

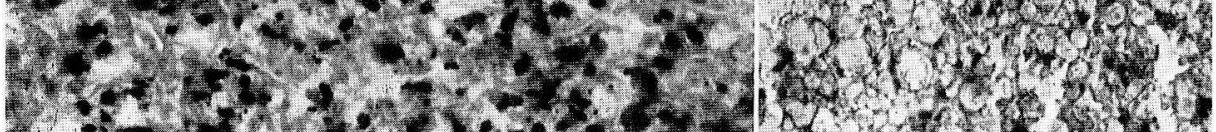

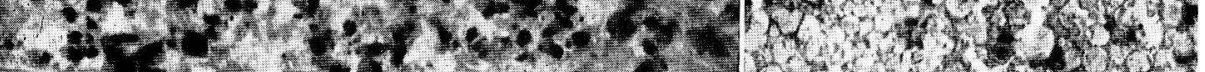

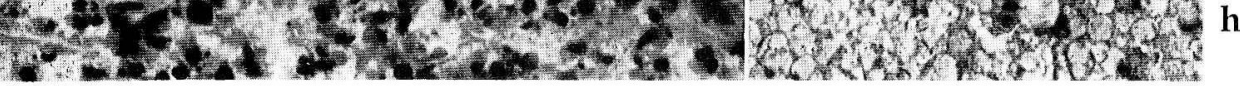



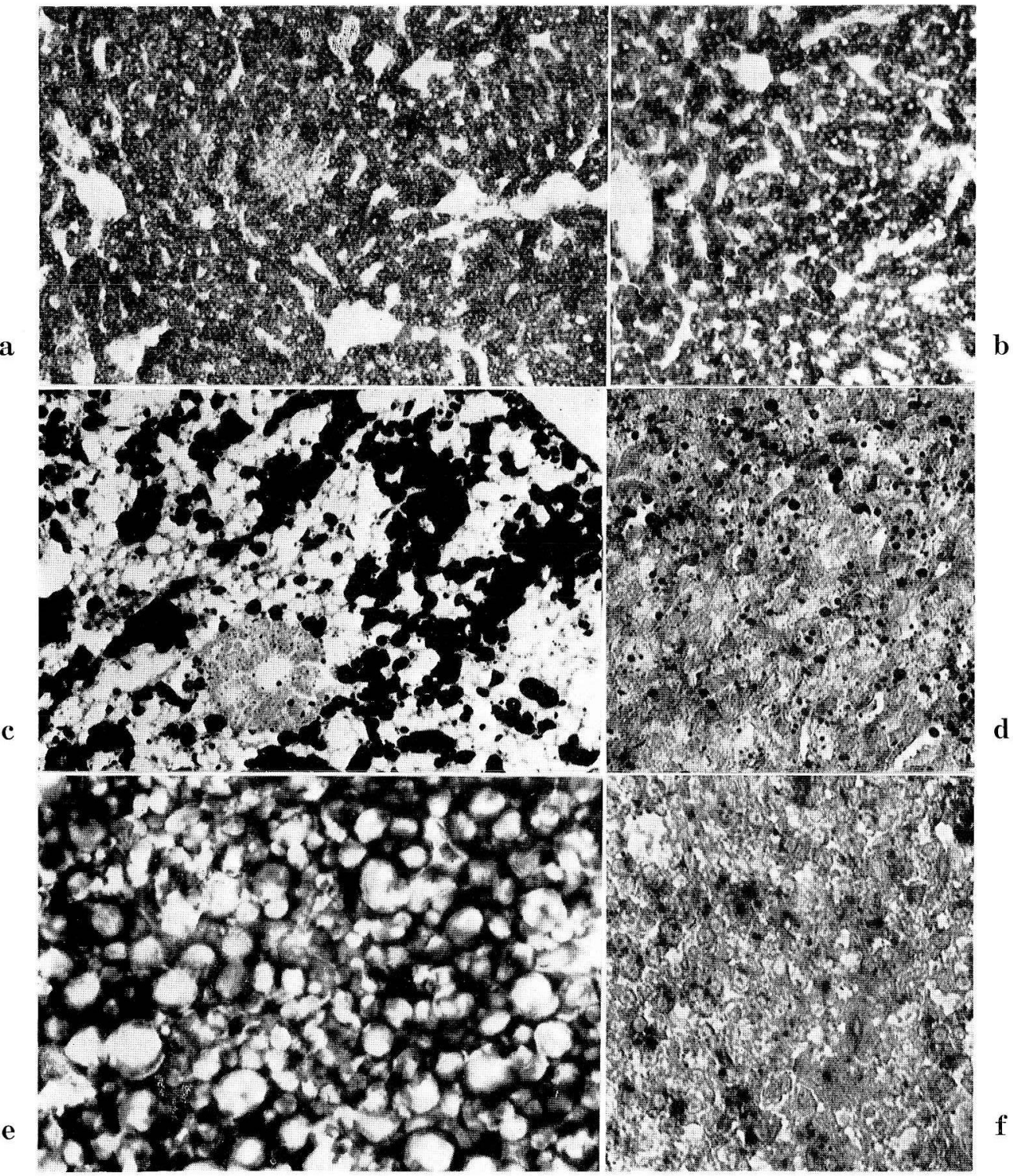

Fig. 2. a. NADH-diaphorase. Gadus. $\times 140$. b. NADPH-diaphorase. Amphiprion. $\times 140$. c and d. Sudan black. c. Tetraodon (note that only part of the lipid droplets are stained). $\times 140$. d. Amphiprion $\times 300$. e. Indoxyl-acetatesterase, Tetraodon $\times 480$. f. E-600 resistent-esterase. Corydoras. $\times 300$

Fig. 1. a and b. Alkaline phosphatase. a. Dascyllus. $\times 140$. b. Corydoras. $\times 300$. c and d. Acid phosphatase. c. Dascyllus. $\times 140$. d. Gadus. $\times 480$. e and f. $\beta$-glucuronidase. e. Amphiprion. $\times 480$. f. Tetraodon. $\times 480 . \quad \mathbf{g}$ and h. $\beta$-glucosaminidase. g. Amphiprion. $\times 300$. h. Tetraodon. $\times 300$ 
possibly also of the bile canaliculi (Limanda, Corydoras). A strong reaction along the sinusoids was found only in Amphiprion, Hippocampus and Dascyllus (Fig. 1a). No reaction along the sinusoids was observed in Tetraodon. In Limanda, Gadus and Corydoras (Fig. 1b) the linings of these vessels exhibited a weak activity of alkaline phosphatase.

Sudan black (Fig. 2c, d). Tetraodon and Limanda contain large amounts of lipid. The lipid droplets in these genera are generally large and their distribution over a sections is slightly uneven; however, no preferred areas of lipid deposition were recognized (Fig. 2c). Gadus contains moderate amounts of lipid which is evenly distributed in the tissue. The lipid droplets are often of medium size and frequently of irregular shape. The hepatocytes of Amphiprion (Fig. 2d) and Dascyllus contain very little lipid, which in Dascyllus is concentrated around central veins. Hippocampus and Corydoras contain almost no liver lipid.

\section{Electron microscopy}

In the following general section the main emphasis has been laid on functionally important areas such as the space of Disse and the bile canaliculi as well as on the appearance and amount of lipid and glycogen, endoplasmic reticulum, mitochondria, lysosomes and peroxisomes.

In all species, besides occasional intracellular bile canaliculi (especially in Amphiprion and Gadus) mainly intercellular canaliculi have been found, which generally are surrounded by two hepatocytes (in Hippocampus by three to four hepatocytes (Fig. 3a)). Occasionally, particularly in Gadus and Hippocampus, also a tonofilamentrich bile duct cell can be among the cells bordering the canaliculus. The hepatocytes extend numerous microvilli into the canalicular lumen (Fig. 3a, b), which is sealed off against the remaining intercellular space between the hepatocytes by junctional complexes. Near the lumen gap junctions occur, the intercellular space being narrowed to about $20 \mathrm{~A}$ (Fig. 3a, b). True tight junctions have not been observed. Proximal to the gap junctions small desmosomes occur, often containing electron-dense intercellular material. Below these small desmosomes rather big ones can make their appearance, which always contain electron-dense intercellular material (Fig. 5d).

A typical space of Disse (Fig. 4a-d) has been observed in all species. The endothelial lining of the sinusoids is frequently extremely thin and partly fenestrated. A basement lamina under the endothelium or over the microvilli of the hepatocytes has never been detected. Occasionally small bundles of collagen fibers appear in the space of Disse as well as individual tonofilament-rich cells, especially in Gadus and Hippocampus, where they are connected by big desmosomes (Fig. 4c, d). These cells contain relatively small and elongated nuclei (Fig. $4 \mathrm{~d}, 7 \mathrm{~b}$ ) and were never found to store lipid droplets. The hepatocytes extend numerous microvilli into the space of Disse (Fig. 4a, b). At their base generally large numbers of spined vesicles occur. In Hippocampus the hepatocytes often contain tonofilaments near the microvilli.

In respect to their contents of energy-rich storage products two groups of hepatocytes can be distinguished: 1) lipid- and 2) glycogen-rich hepatocytes. The livers of Tetraodon and Limanda contain cells of the first type; in the other species glycogen preodominates, Gadus taking an intermediate position. In Tetraodon and Limanda (Fig. 7a) the cytoplasm of the hepatocytes is usually confined to relatively narrow 


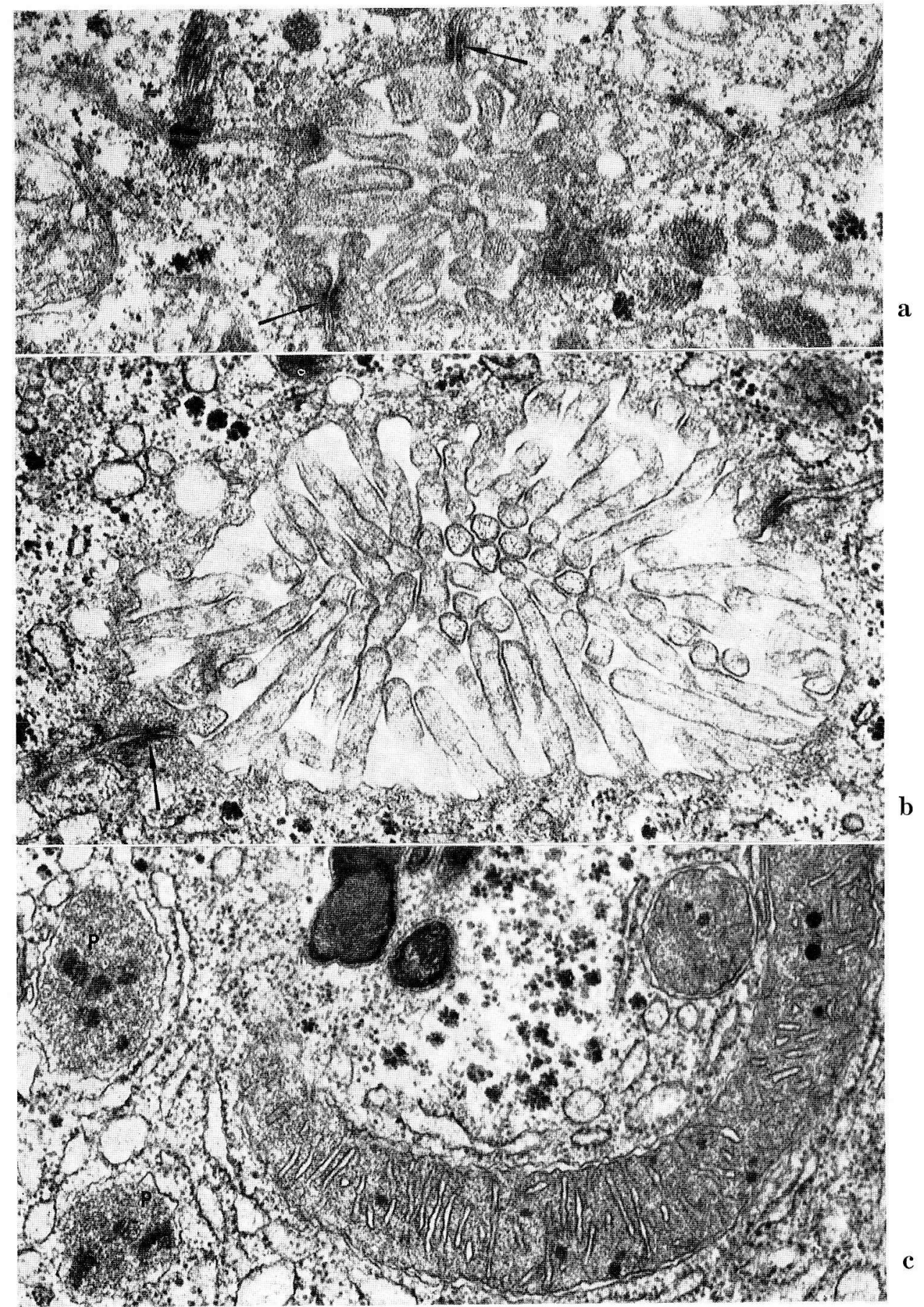

Fig. 3. a and b. Bile canaliculus between hepatocytes. a. Hippocampus. $\times 30,000$. b. Corydoras. $\times 24,000$. Arrows point to gap junctions. c. Mitochondria and peroxisomes $(P)$. Corydoras. 


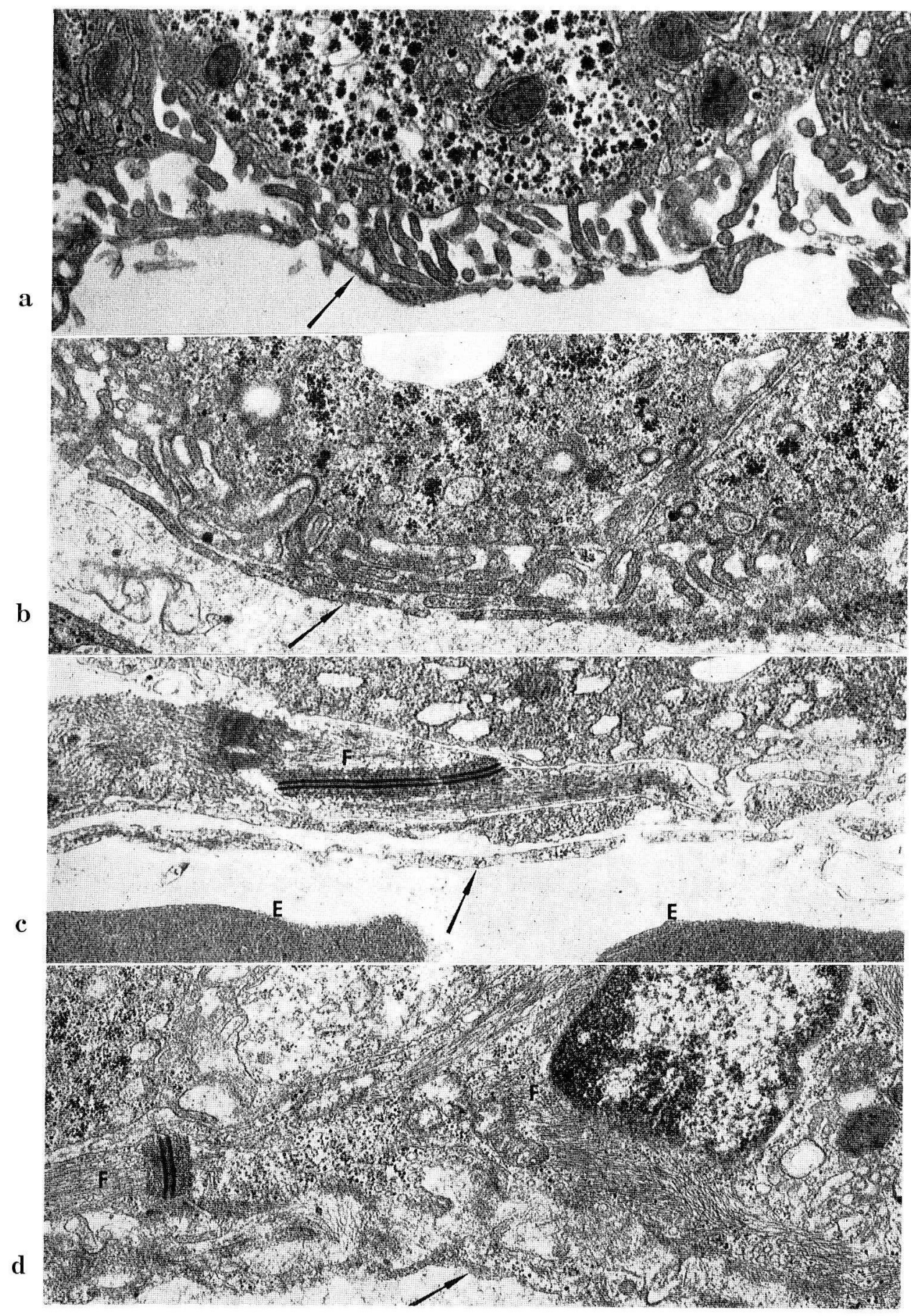

Fig. 4. Space of Disse. a. Corydoras, arrow points to endothelium of sinusoid. $\times 18,000$. b. Hippocampus. $\times 18,000$. c. Gadus. $\times 18,000$. d. Hippocampus. $\times 18,000$. Note filament-rich cells $(F)$ interconnected by desmosomes in the space of Disse of Gadus and Hippocampus. E erythrocytes. 


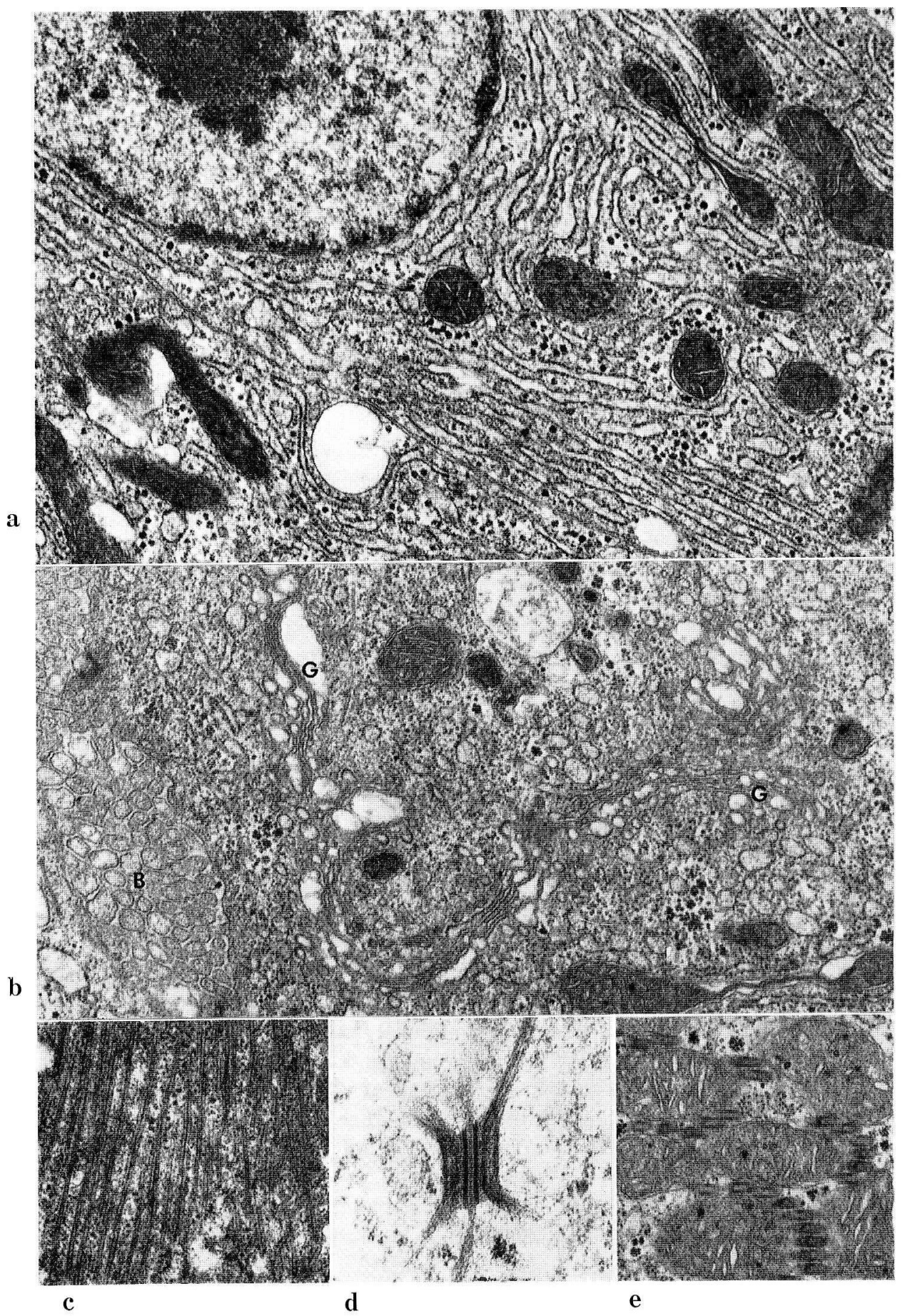

Fig. 5. a. ER-rich hepatocytes of Dascyllus. $\times 18,000$. b. Extensive Golgi-apparatus $(G)$ in Corydoras. $B$ bile canaliculus. $\times 18,000$. c. Linear substructures in the hepatocytes of Limanda. $\times 18,000$. d. Desmosome between two hepatocytes. Hippocampus. $\times 20,000$. e. Tubular structures in the hepatocytes of Corydoras. $\times 18,000$ 
areas between the lipid droplets, which are particulary large in Tetraodon. In both species the lipid is electron-transparent. The same is true of the other species except for Gadus, which contains relatively electron-dense lipid inclusions.

Glycogen is particularly prominent in the hepatocytes of Chromis, Corydoras and Amphiprion, where it occupies large areas containing only this substance. Reduced amounts occur in the hepatocytes of Dascyllus and Hippocampus; Gadus hepatocytes contain only relatively few glycogen particles. Limanda and Tetraodon liver cells contain in addition to their numerous lipid inclusions moderate amounts of glycogen. The glycogen always appears in the form of alpha-particles, the size of which can differ markedly (Fig. 3c, 4a, b, 6d).

Endoplasmic reticulum occurs both in the rough and the smooth variety. The rough type is a dominant organelle in the hepatocytes of Corydoras, Dascyllus (Fig. 5a) and Gadus. In these species it forms stacks, consisting of about five cisterns. Smooth endoplasmic reticulum was never observed in large quantities. Both smooth and (more frequently) rough reticula have been found in close spatial relationship to peroxisomes.

The Golgi-apparatus is generally of small dimensions and is situated near the bile canaliculi. Only in Corydoras this organelle is more voluminous (Fig. 5b).

Mitochondria are of different appearance and occur in different numbers in the individual species. In Corydoras (Fig. 3c) they appear in moderate numbers, but are relatively long and contain numerous cristae or tubules (round and triangular profiles). The matrix is generally electron-dense, with the exception of Gadus, where it is rather transparent. Intramitochondrial granules are particularly frequent in Corydoras, but also occur in the other species, where the mitochondria are generally small and of roundish or oval shape. In the cod mitochondria are particularly abundant. This is also true of Tetraodon, where they often surround the lipid inclusions.

Lysosomes occur only in moderate quantities in our material (Fig. 7b). They often are located in the apical cytoplasm near the bile canaliculi. In Gadus they occasionally contain remnants of mitochondria.

Membrane-bound inclusions with a homogeneous fine granular matrix correspond — - according to their ultrastructure-to peroxisomes; they are comparatively common (Fig. 3c, 6b, c, d). Two main types can be distinguished on the basis of the presence or absence of a core. In the first group peroxisomes often can be found having several cores (e.g. in Corydoras), which are irregularly distributed in a fine granular matrix (Fig. 3c, 6b). The peroxisomes without the core are of various dimensions and generally surrounded by rough ER cisterns (Fig. 6a). Less frequently they are in close proximity to smooth cisterns (Fig. 6d). Possibly also the structures which are frequently to be seen in the hepatocytes of Hippocampus belong to this group of organelles. They represent inflated roundish cisterns of rough endoplasmic reticulum containing rather dense contents, which later on may loosen up.

The nature of other types of inclusion body, which has often been seen in the hepatocytes of Hippocampus (Fig. 6a), remains undetermined. They are membranebound and often contain an electron dense center, which is surrounded by small vesicular elements.

In the following section brief descriptions of the main ultrastructural characteristics of the hepatocytes in the species investigated shall be given. 


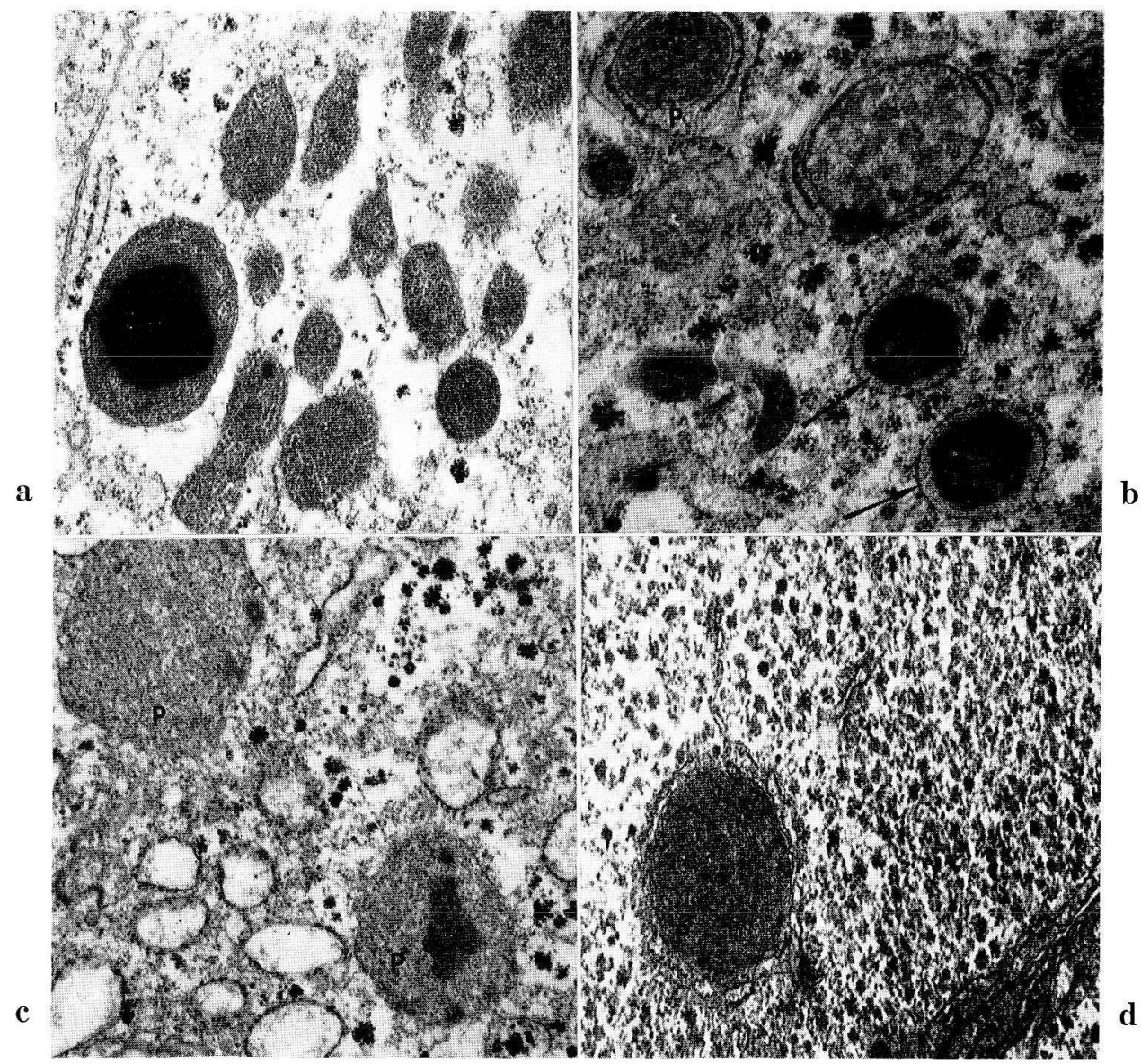

Fig. 6. a and b. Various inclusion bodies in the hepatocytes of Hippocampus. $P$ peroxisome. Arrows point to inflated rough ER cisterns containing electron dense material. a: $\times 18,000$, b: $\times 24,000$. c. Peroxisomes $(P)$ in a hepatocyte of Corydoras. $\times 24,000$. d. Peroxisome $(P)$ in a field of glycogen in a hepatocyte of Amphiprion. $\quad \times 24,000$

Gadus. Relatively infrequent and dark lipid inclusions, almost no glycogen. Abundant rough endoplasmic reticulum and many small and light mitochondria, comparatively numerous lysosomes, few and small peroxisomes,

Tetraodon. Numerous lipid inclusions, moderate numbers of glycogen particles. Mitochondria comparatively elongated, rough endoplasmic reticular cisterns relatively well developed, few lysosomes and peroxisomes.

Dascyllus. Few lipid inclusions, few glycogen particles, very well developed rough endoplasmic reticulum (Fig. 5a), moderate numbers of mitochondria, peroxisomes infrequent.

Chromis. Few lipid inclusions, large fields of glycogen, rather few endoplasmic reticular cisterns with ribosomes, moderate numbers of roundish mitochondria, peroxisomes large and relatively frequent.

Limanda. Numerous lipid inclusions, in the remaining cytoplasm moderate 


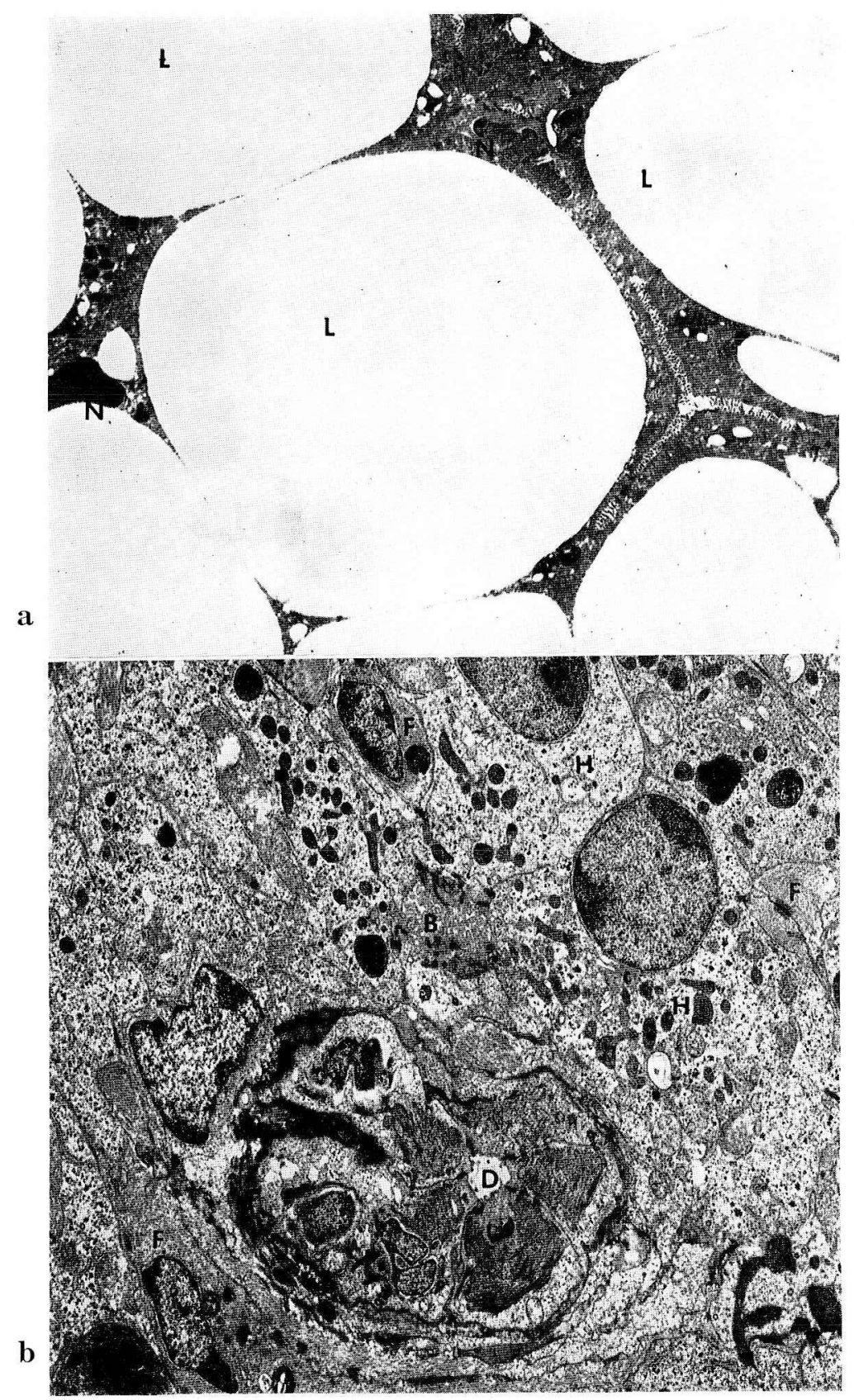

Fig. 7. a. Low power electron micrograph of lipid-containing hepatocytes of the flat-fish Limanda. $N$ nucleus of hepatocytes. $L$ lipid droplets. $\times 2,700$. b. Small biliary duct $(D)$, bile canaliculus $(B)$, hepatocytes $(H)$ and filamentcontaining cells $(F)$ in the liver of Hippocampus. $\times 5,800$ 
numbers of glycogen-particles and cisterns of rough endoplasmic reticulum, small elongated mitochondria, moderate numbers of peroxisomes. Frequently straight, possibly tubular elements running in parallel, occur (Fig. 5c).

Hippocampus. Almost no lipid, numerous glycogen particles, rough endoplasmic reticulum and mitochondria infrequent, peroxisomes relatively numerous. Many typical inclusions containing microvesicular particles and electron dense areas (Fig. $6 a)$.

Corydoras. Very few lipid inclusions, abundant glycogen particles, well-developed rough endoplasmic reticulum, moderate numbers of strikingly elongated mitochondria with numerous infoldings of the inner membrane and intramitochondrial granules, peroxisomes (with core) frequent. In the neighborhood of the mitochondria occasionally relatively thick-walled tubular structures occur (Fig. 5e). This is the only species with a well-developed Golgi-apparatus.

Amphiprion. Few lipid-inclusions, large fields of gycogen-particles, few cisterns of rough endoplasmic reticulum, moderate numbers of oval mitochondria, few large peroxisomes which often are surrounded by smooth endoplasmic reticulum and located in glycogen fields.

\section{Discussion}

The results of the present investigation lend support to the assumption that genetically fixed species differences exist among teleost fishes in respect to lipid and carbohydrate metabolism (Ito, Watanabe and TAKAhashi, 1962; PhiLipps, 1969) since specimens of various species were kept under identical conditions for several weeks. A correlation between these physiological characteristics and the mode of life could not be found, since, e.g., species living in such diverse habitats as the Baltic Sea (Limanda limanda) and SE-Asian tropical rivers (Tetraodon fluviatilis) can show great similarities in respect of the amount of stored liver lipid, whereas hepatocytes of species originating from the same habitat can exhibit numerous histochemical and ultrastructural differences. This assumption does not exclude seasonal, temperature, age and diet depending differences in regard to the metabolism of the energy-rich storage products in the liver of fish as have been described by HoAR and CotTLE (1952), Ebitani (1961ab, 1962), Philipps (1969).

The fact that in the liver of Dascyllus lipid and glycogen occur only in small amounts even suggests that in some fish species this aspect of metabolism - at least temporarily_ _ is relatively unimportant and that secretory phenomena may play a major rôle as can be inferred from the predominant rough endoplasmic reticulum. In comparison with mammalian liver cells the relatively small Golgi apparatus and the few lysosomes deserve attention. This finding indicates that possibly the production of bile is reduced or follows different patterns in the teleosts, since lysosomes are thought to play a rôle in the transport of biliary pigments (DvORAK and Horky, 1967). KitAMIKADO and TACHINo (1961) found high concentrations of esterases in the bile of the rainbow trout.

The crista- and tubule-rich mitochondria of the hepatocytes of a few species, especially Corydoras, exhibit a markedly different ultrastructure in comparison with those of amphibians (WeLsch and STORCH, 1972) and mammals (Novikoff and Holtzman, 1970), in which the cristae are usually reduced and the matrix predominates. In 
Corydoras the mitochondria resemble those found in pancreatic acinar cells.

Recently peroxisomes have been detected in numerous tissues and could even be divided into several subgroups (Novikoff et al., 1972). These authors stress their structural and functional heterogeneity. Organelles, which according to their ultrastructure are interpreted to represent peroxisomes, are relatively abundant in the liver cells of teleosts and were found in close connection with rough and smooth endoplasmic reticulum. In the latter case they can be classified as microperoxisomes according to Novikoff et al. (1972), although in the fishes they may be rather big. In some species, e.g. in Corydoras, they possess a core, which in anurans was correlated with the enzyme allantoinase (VISENTIN and ALLEN, 1969) or urate oxidase in mammals (Novikoff and Holtzman, 1970). Since experimental data are apparently lacking on teleost liver cells, no definite statements can be made on the function of these organelles in this tissues; however, the suggestion of NoviKufF and others (1972) that in the mammalian jejunum microperoxisomes may play a functional rôle in lipid metabolism and transport may also apply to the lipid-rich liver cells of fish. For further discussion of the function of peroxisomes see DE DUVE and BAUDHUIN (1966) and HRUBAN and ReCHCIGL (1969).

In respect to the bile canaliculi we can modify the statements of DAvID (1961) and YАмАмото (1965) by saying that, beside intracellular, numerous intercellular bile canaliculi occur in the liver of teleosts. The situation as described by the abovementioned authors in the goldfish is somewhat similar to that found in the cod (Gadus) in our material. In the other species intercellular canaliculi predominate. The junctional complexes sealing off the bile canaliculi differ from those known in mammals (Nicolescu and Rouiller, 1967; Matter, Orci and Rouiller, 1969). True tight junctions have not been found in the teleosts.

The morphology of the space of Disse can differ in various higher vertebrates (Wood, 1963). That of teleosts is characterized by a poor development of connective tissue structures and by the absence of a basement lamina. It thus may be even more efficient in regard to exchange and transport of substances than the space of Disse of many mammals, e.g. ungulates (Wood, 1963). In the space of Disse of the teleosts investigated small numbers of filament rich cells can be found; they are most frequent in Gadus and Hippocampus. It remains an open question whether these cells correspond to the fat-storing cells of ITO, which occur in the space of Disse in various vertebrates (ITo and SHIBASAKI, 1968). In respect to their high contents of filaments, they resemble the cells bordering small biliary ducts. The microvilli of the hepatocytes extending into the space are generally numerous and at their bases large numbers of spined vesicles occur. Both features also indicate high rates of transport processes.

In the same way we interpret our findings in regard to alkaline phosphatase activity. In our material this enzyme mainly occurs along the sinusoids and possibly along the canaliculi. Presumably it is located on the surface of the hepatocytes as is thought to be the case in anurans by SARKAR and DeB (1965). In those species in which the microvilli of the hepatocytes, which extend into the space of Disse, are poorly developed, alkaline phosphatase also exhibits only a weak activity, as in the case of the lipid-rich hepatocytes of Tetraodon and Limanda. Strong activity of this enzyme was found in Amphiprion, Hippocampus and Dascyllus, among which Amphiprion and 
Hippocampus contain large numbers of glycogen-particles, whereas Dascyllus is relatively poor in both glycogen and lipid. Thus in teleosts as in tetrapods (SARKAR and DEB, 1965) no clear correlation between alkaline phesphatase and glycogen contents exists.

In contrast to the findings of Bouchilloux (1950) and SARKar and DeB (1965) on alkaline phosphatase in various fishes, we observed a predominant localization at the periphery of the hepatocytes, whereas the above mentioned authors found a predominant intracellular lacalization. Whereas the peripheral localization also occurs in other tissues with microvilli-bearing surfaces active in transport, it is difficult to find an explanation for the intracellular localization. Cholin-esterase shows a localization in the liver of some of the teleosts investigated similar to alkaline phosphatase; however, no correlation exists between the occurence of the two enzymes. Presumably the cholinesterase demonstrated is butyryl-cholin-esterase, which is known to occur, for example, outside the endothelia of certain blood vessels. Nerves have not been found in the space of Disse. The activity of this enzyme is weak or absent in the species with a hight content of liver lipid (Tetraodon, Limanda and also Gadus), but also in Amphiprion and Hippocampus.

Although the precise identity of the two flavoprotein-diaphorases has not yet been determined (PEARSE, 1968), they play a rôle in electron transport and thus can be taken as indicators of energy producing metabolism which evidently is strong also in the lipid-rich cells of Tetraodon and Limanda, the exception being Hippocampus which also has relatively few mitochondria in its hepatocytes.

The generally lysosomal enzymes such as acid phosphatase, $\beta$-glucuronidase, $\beta$ glucosaminidase and $\beta$-galactosidase are, in the teleost hepatocytes, usually moderate or even weak in activity which corresponds to the infrequent occurrence of lysosomes as has been seen in the electron microscope. The actual in vivo function of all these enzymes is seldom clear. PeArse (1972) discusses their possible functions. $\beta$ glucosaminidase is presumably engaged in the degradation of oligosaccharide fragments, $\beta$-galactosidase may hydrolyse lactose and degrade glycoprotein carbohydrates. Of especial interest is the occurrence of $\beta$-glucuronidase in the fish hepatocytes since this enzyme is believed to play, among others, a rôle in the conjugation of steroid hormones and participate in cellular proliferation. Some evidence indicates that its rôle in steroid metabolism presumably is catabolic, thus the liver of teleosts may, similarly to that of mammals, be involved in the degradation of steroid hormones.

\section{References}

Bouchilloux, S.: Phosphatases of the liver and various organs of fishes. C. r. Soc. Biol. 144: 15321533 (1950).

Braus, H.: Untersuchungen zur vergleichenden Histologie der Leber der Wirbeltiere. Jena Denkschr. V, 4: 303-367 (1896).

Burstone, M. S.: Histochemical comparison of naphthol-AS-phosphates for the demonstration of phosphatases. J. Nat. Cancer Inst. 20: 601-608 (1958).

David, H.: Zur submikroskopischen Morphologie intrazellulärer Gallenkapillaren. Acta anat. (Basel) 47: 216-224 (1961). 
de Duve, C. and P. Baudhuin: Peroxisomes (microbodies and related particles). Physiol. Rev. 46: 323-348 (1966).

Dvorak, M. and D. Horky: Submikroskopische Struktur der Leberzelle nach Beeinflussung ihrer. Sekretionstätigkeit. Z. Zellforsch. 76: 486-497 (1967).

Eberth, C. J.: Untersuchungen über die Leber der Wirbeltiere. Arch. mikrosk. Anat. 3: 423-440 (1867).

Ebitani, Y.: On the relation beteen fish-liver and temperature conditions. I. Arch. histol. jap. 21: 491-509 (1961a).

: On the relation between fish-liver and temperature conditions. II. Arch. histol. jap. 21: 521-533 (1961b).

-: On the relation between fish-liver and temperature conditions. III. Arch. histol. jap. 22: 101-115 (1962).

Elias, H. und H. Bengelsdorf: The structure of the liver of vertebrates. Acta anat. 14: 297-337 (1952).

Gomori, G.: Microscopic histochemistry. Principles and practice. Chicago, University Press, 1952.

Hering, E.: Über den Bau der Wirbeltierleber. Arch. mikrosk. Anat. 3: 88-114 (1867).

Hoar, W. S. and M. K. Cottle: Dietary fat and temperature tolerance of goldfish. Can. J. Zool. 30: 41-48 (1952).

Holt, S. J.: Indigogenic staining methods for esterases. In: (ed. by) J. F. Danielli: General cytochemical methods. New York, Academic Press, 1958. (vol. 1, p 375-398).

Hruban, Z. and M. Recheigl: Microbodies and related particles. Int. Rev. Cytol. suppl. 1. (1969).

Ito, T. and S. Shibasaki: Electron microscopic study on the hepatic sinusoidal wall and the fat storing cells in the normal human liver. Arch. histol. jap. 29: 137-192 (1968).

Ito, T., A. Watanabe und Y. Takahashi: Histologische und cytologische Untersuchungen der Leber bei Fisch und Cyclostomata nebst Bemerkungen über die Fettspeicherzellen. Arch. histol. jap. 22: 429-463 (1962).

Kitamikado, M. and S. Tachino: Digestive enzymes of the rainbow trout III. Chem. Abstr. 55: $5789 \mathrm{c}(1961)$.

Krause, R.: Mikroskopische Anatomie der Wirbeltiere in Einzeldarstellungen. Berlin, W. de Gruyter, 1921.

Matter, A., Orci, L. and Ch. Rouiller: A study on the permeability barriers between Disse's space and the bile canaliculus. J. Ultrastruct. Res. Suppl. 11: 1-71 (1969).

Nicolescu, P. und Ch. Rouiller: Beziehungen zwischen den Endothelzellen der Lebersinusoide und den von Kupfferschen Sternzellen. Z. Zellforsch. 76: 313-338 (1967).

Novikoff, A. B. and E. Holtzman: Cells and organelles. New York, Holt, Rinehart and Winston, Inc., 1970.

Novikoff, A. B, Ph. M. Novikoff, C. Davis and N. Quintana: Studies on microperoxisomes. II. J. Histochem. Cytochem. 20: 1006-1023 (1972).

Pearse, A. G. E.: Histochemistry-Theoretical and applied. 3rd ed. London. J. \& A. Churchill Ltd., Vol. 1. 1968; Vol. 2. 1972.

Philipps, A. M.: Nutrition, digestion and energy utilisation. In: (ed. by) W. S. Hoar and D. J. Randall: Fish physiology. New York-London, Academic Press, 1969. (p. 391-432).

Pugh, D. and P. G. Walker: Histochemical localization of $\beta$-glucuronidase and $\mathrm{N}$-acetyl- $\beta$-glucosaminidase. J. Histochem. Cytochem. 9: 105-106 (1961).

Romeis, B.: Taschenbuch der mikroskopischen Technik. 16. Aufl. München, Oldenbourg, 1968.

Rutenberg, A. M., S. H. Rutenberg, B. Moris, R. Teague and A. M. Seligman: Histochemical demonstration of $\beta$-D-galactosidase in the rat. J. Histochem. Cytochem. 6: 122-129 (1958).

Sarkar, Ch. and Ch. Deb: Histochemical study on the distribution of alkaline and acid phosphatase in liver of different classes of vertebrates. Acta anat. 62: 53-59 (1965).

Shore, T. W. and H. L. Jones: On the structure of the vertebrate liver. J. Physiol. 10: 408-428 (1889). 
Siwe, S. A: Die Leber. In: (hg. von) L. Bolk, E. Göppert, E. Kallius und W. Lubosch: Handbuch der vergleichenden Anatomie der Wirbeltiere. III. Berlin-Wien, Urban und Schwarzenberg, 1937. (S. 725-774).

Visentin, L. P. and J. M. Allen: Alantoinase: association with amphibian hepatic peroxisomes. Science 163: 1463-1464 (1969).

Welsch, U. und V.Storch: Elektronenmikroskopische Untersuchungen an der Leber von Ichthyophis kohtaoensis (Gymnophiona). Zool. Jhrb. Anat. 89: 621-635 (1972).

Wood, R. L.: Evidence of species difference in the ultrastructure of the hepatic sinusoid. Z. Zellforsch. 58: 679-692 (1968).

Yamamoto, T.: Some observations of the fine structure of the liver cells in the starved gold fish (Carassius auratus), with special reference to the morphology of fat mobilization during starvation to the liver. Arch. histol. jap. 24: 335-345 (1964).

: Some observations on the fine structure of the intrahepatic biliary passage in goldfish (Carassius auratus). Z. Zellforsch. 65: 319-330 (1965).

Dr. Ulrich N. WeLsCH

Anatomisches Institut der Universität

$23 \mathrm{Kiel}$

Olshausenstr. 40-60

Germany 